\title{
Analysis of Technology Options to Reduce the Fuel Consumption of Idling Trucks
}

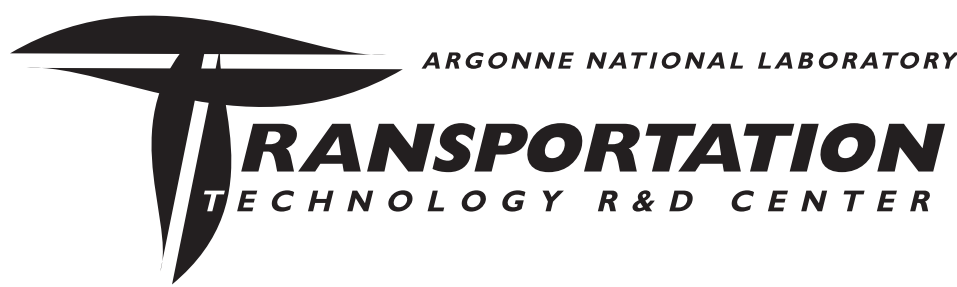

Center for Transportation Research Argonne National Laboratory

Operated by The University of Chicago, under Contract W-31-109-Eng-38, for the

United States Department of Energy 


\section{Argonne National Laboratory}

Argonne National Laboratory, with facilities in the states of Illinois and Idaho, is owned by the United States Government and operated by The University of Chicago under the provisions of a contract with the Department of Energy.

This technical report is a product of Argonne's Energy Systems Division.

For information on the division's scientific and engineering activities, contact:

Director, Energy Systems Division

Argonne National Laboratory

Argonne, Illinois 60439-4815

Telephone (630) 252-3724

Publishing support services were provided by Argonne's Information and Publishing Division (for more information, see IPD's home page: http://www.ipd.anl.gov/).

\section{Disclaimer}

This report was prepared as an account of work sponsored by an agency of the United States Government. Neither the United States Government nor any agency thereof, nor The University of Chicago, nor any of their employees or officers, makes any warranty, express or implied, or assumes any legal liability or responsibility for the accuracy, completeness, or usefulness of any information, apparatus, product, or process disclosed, or represents that its use would not infringe privately owned rights. Reference herein to any specific commercial product, process, or service by trade name, trademark, manufacturer, or otherwise does not necessarily constitute or imply its endorsement, recommendation, or favoring by the United States Government or any agency thereof. The views and opinions of document authors expressed herein do not necessarily state or reflect those of the United States Government or any agency thereof, Argonne National Laboratory, or The University of Chicago.

Available electronically at http://www.doe.gov/bridge Available for a processing fee to U.S. Department of Energy and its contractors, in paper, from:

U.S. Department of Energy Office of Scientific and Technical Information P.O. Box 62

Oak Ridge, TN 37831-0062

phone: (865) 576-8401

fax: (865) 576-5728

email: reports@adonis.osti.gov 


\section{Analysis of Technology Options to Reduce the Fuel Consumption of Idling Trucks}

by Frank Stodolsky, Linda Gaines, and Anant Vyas

Center for Transportation Research, Energy Systems Division,

Argonne National Laboratory, 9700 South Cass Avenue, Argonne, Illinois 60439

June 2000

Work sponsored by the United States Department of Energy,

Assistant Secretary for Energy Efficiency and Renewable Energy,

Office of Transportation Technologies, Office of Heavy Vehicle Technologies 
This report is printed on recycled paper. 


\section{Contents}

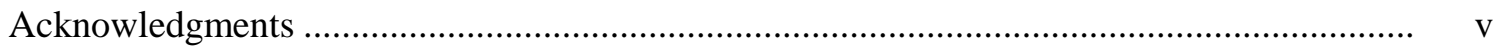

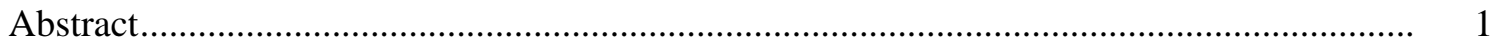

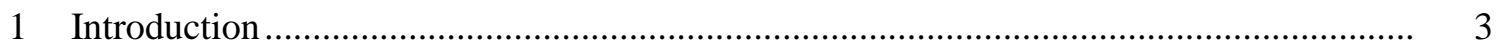

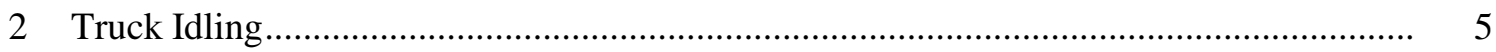

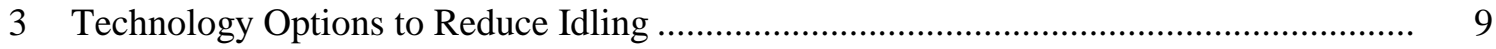

4 Potential Implications of New Technologies ............................................................ 15

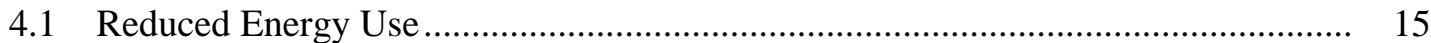

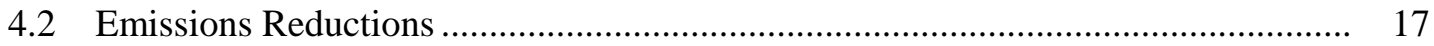

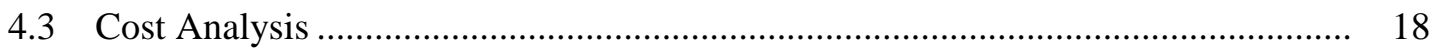

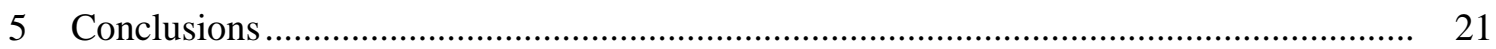

5.1 National Benefits ............................................................................ 21

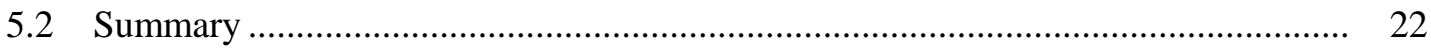

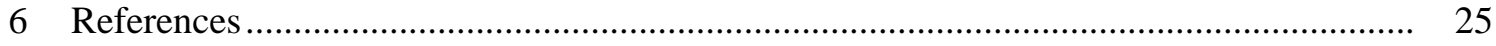

\section{Appendixes}

Appendix A: Equipment and Emissions Data ................................................................ 29

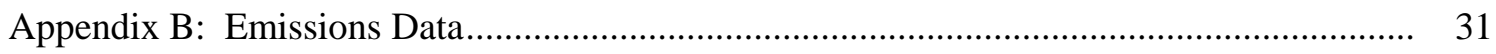

\section{Figures}

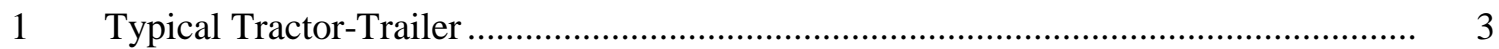

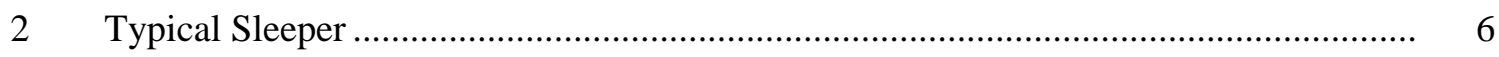

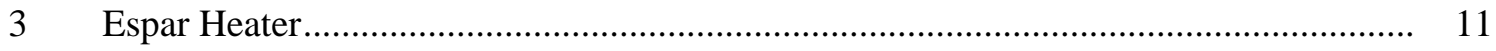

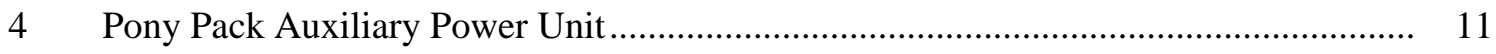

$5 \quad$ Webasto Thermocooler ${ }^{\circledR}$, Auxiliary Climate Control System..................................... 12 
$\Delta$

\section{Tables}

$1 \quad$ Estimated Idling Hours for Long-Haul Trucks ....................................................... 7

2 Technology Options for Reducing Overnight Diesel Engine Idling ........................... 10

3 Estimated Cab/Sleeper Heating and Engine Block Heating

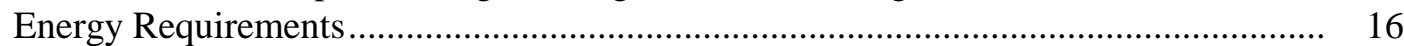

$4 \quad$ Estimated Emissions from Truck Cab/Sleeper and Engine Block Heating ................... 18

5 Economic Analysis of Equipment Options, as Function

of Idling Hours Displaced .................................................................................... 20

6 Baseline Annual Heating/Cooling Energy Use and $\mathrm{CO}_{2}$ Emissions

for $100 \%$ Market Penetration by Alternative Technologies ......................................... 22

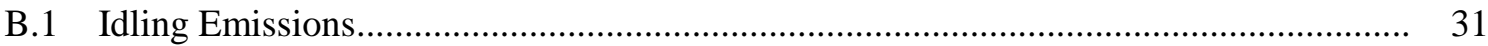

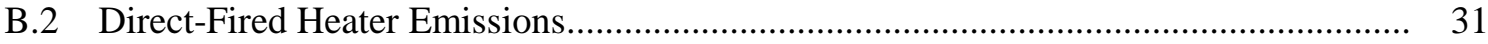

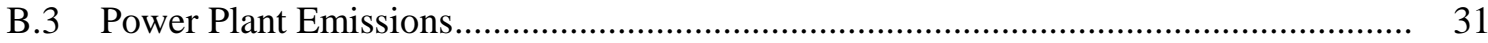

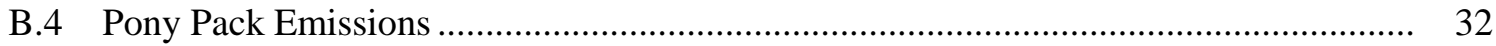




\section{Acknowledgments}

The authors wish to thank Sidney Diamond, Program Manager, Office of Heavy Vehicle Technologies, and James J. Eberhardt, Director, Office of Heavy Vehicle Technologies. We also thank the other members of the Center for Transportation Research who helped with this study: Rolando (Roy) Cuenca, Kenneth Wilund, Margaret Singh, and Michael Wang. In addition, we thank Jules Routbort for facilitating contacts among the parties involved. The authors also thank equipment vendors, trucking companies, and trucking organizations for their constructive comments on the earlier draft. 
$\Delta$ 


\section{Abstract}

Long-haul trucks idling overnight consume more than 838 million gallons (20 million barrels) of fuel annually. Idling also emits pollutants. Truck drivers idle their engines primarily to (1) heat or cool the cab and/or sleeper, (2) keep the fuel warm in winter, and (3) keep the engine warm in the winter so that the engine is easier to start. Alternatives to overnight idling could save much of this fuel, reduce emissions, and cut operating costs. Several fuel-efficient alternatives to idling are available to provide heating and cooling: (1) direct-fired heater for cab/sleeper heating, with or without storage cooling; (2) auxiliary power units; and (3) truck stop electrification. Many of these technologies have drawbacks that limit market acceptance. Options that supply electricity are economically viable for trucks that are idled for 1,000-3,000 or more hours a year, while heater units could be used across the board. Payback times for fleets, which would receive quantity discounts on the prices, would be somewhat shorter. 
$\Delta$ 


\section{Section 1 Introduction}

Intercity tractor-trailers (like the one shown in Figure 1) and other vehicles with diesel engines idle a significant portion of the time. A typical intercity tractor-trailer idles an estimated $1,830 \mathrm{~h} / \mathrm{yr}$ when parked overnight at truck stops. Nationally, a significant amount of fuel is consumed this way - trucks that travel more than $500 \mathrm{mi} / \mathrm{d}$ consume about 838 million gal of diesel fuel annually during idling. Drivers have many reasons for keeping the diesel engine running in a tractor-trailer: (1) to keep the cab and/or sleeper heated or cooled, (2) to keep the fuel warm in winter, (3) to keep the engine warm in the winter to permit easier startup, and (4) because all the other drivers do it (LaBelle 1986). Other trucks and vehicles with diesel engines are also idled for long periods: school bus drivers idle their buses in the morning to defrost the windshield and heat the bus, and transit bus drivers idle their buses to heat or cool the bus while waiting to pick up passengers at terminals (Jessiman 1996). Off-highway vehicles and locomotives are idled to keep the engine and fuel warm in cold weather.

Idling also produces airborne emissions and noise; a number of cities and municipalities have banned or restricted idling to reduce pollution and noise. For example, Philadelphia bans idling of heavy-duty diesel-powered motor vehicles (City of Philadelphia 1986). Exceptions are made during cold weather. Idling is limited to up to 5 consecutive minutes when the ambient temperature is less than $32^{\circ} \mathrm{F}$ and up to 20 minutes when the ambient temperature is less than $20^{\circ} \mathrm{F}$. Buses may be idled up to 20 consecutive minutes if they are equipped with airconditioning and the ambient temperature is $75^{\circ} \mathrm{F}$ or greater.

Various off-the-shelf technologies are available to heat and cool the sleeper and cab of a truck and to keep the engine and fuel warm in the winter without idling the engine. However, many of these technologies have drawbacks that limit market acceptance. Other technologies are less mature but promise to eliminate the drawbacks of the current technologies. This report presents a brief overview of (1) the extent of truck diesel engine idling, (2) technology options to reduce truck diesel engine idling, (3) estimated energy and emissions impacts of each technology option, and (4) the estimated cost of each technology option. A more detailed analysis of technology options, costs, and benefits is recommended, given the potentially significant energy

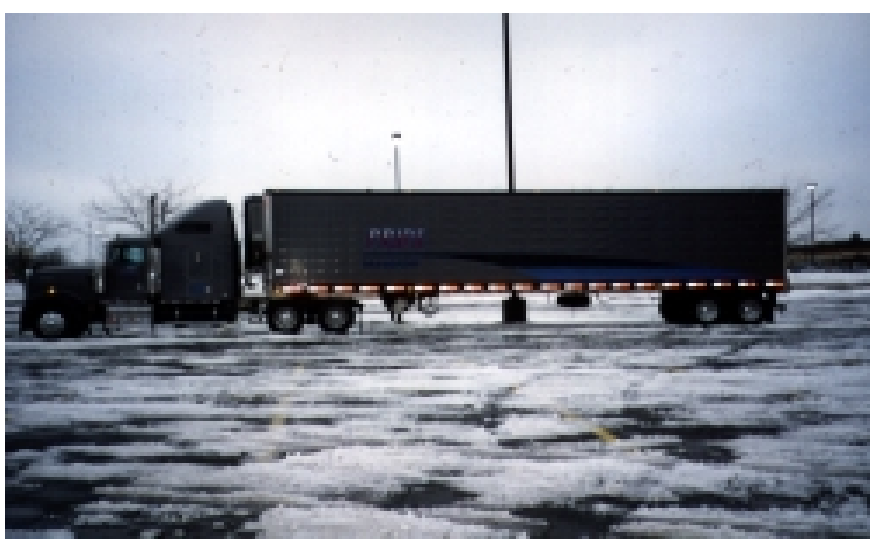

Figure 1 Typical Tractor-Trailer savings and emissions benefits from reducing truck diesel engine idling. 
$\Delta$ 


\section{Section 2 Truck Idling}

The 1997 Vehicle Inventory and Use Survey reports that 2.54 million trucks had a manufacturer's gross vehicle weight $(\mathrm{GVW})$ rating of $26,001 \mathrm{lb}$ or greater, and these trucks are classified as class 8 trucks (VIUS 2000). They may be single-unit trucks or combination trucks (single-unit trucks with a trailer or tractor-trucks with single, double, or triple trailers). Seventy percent of these trucks are operated within $200 \mathrm{mi}$ from the home base, and $83 \%$ are operated within $500 \mathrm{mi}$ of home base. However, about 458,000 combination trucks travel more than $500 \mathrm{mi}$ from their home base each day. Most, but not all, of these trucks are equipped with sleepers. These are the trucks that are likely to be idling overnight during stopovers on long trips.

Drivers idle their truck engines to keep the cab and sleeper area warm when they are sleeping or resting in the truck (or away but likely to return soon); in extremely cold weather, drivers idle their truck engines to keep fuel from freezing and to keep the engine block warm to prevent difficult starting and smoke. They also idle the engines to run air-conditioning during hot weather and to provide power for appliances and other electrical devices. Sleepers can be quite comfortable and well equipped with modern conveniences, such as personal computers, stereos, and televisions. Figure 2 shows a typical sleeper compartment.

Detailed data on idling are not available. However, industry sources have provided rough estimates. One source reports that a long-distance, freight-hauling, heavy-duty truck idles about $6 \mathrm{~h} / \mathrm{d}$ on the average (TMC 1995). The actual extent of idling varies with the season and with the type of operation. A truck may idle for $10 \mathrm{~h} / \mathrm{d}$ during winter and less than $5 \mathrm{~h} / \mathrm{d}$ the rest of the year; the baseline entry in Table 1 reflects a $6-\mathrm{h} / \mathrm{d}$ average, ${ }^{1}$ with a seasonal peak in the winter. Another source estimates that the average is higher - $40 \%$ of the time is spent idling - on the basis of information provided by J.B. Hunt (Whiteside 1996). Most trucking organizations now offer incentives to reduce idling, and some large firms have succeeded in reducing truck idling time to $20 \%$ (Whiteside 1996). However, nearly $40 \%$ of the long-haul trucks are in fleets of less than 25 vehicles, and these small fleets are less likely to have such incentive programs.

We interviewed several truck operators and fleet owners and found a wide variation in actual behavior. At one extreme, one owner-operator of an older truck reported that he leaves his truck running all the time, even at home over the weekend, to make absolutely sure that it will start. On an annual basis, he idles his truck for more than 5,000 h. At the other extreme is another owner-operator, who lives in Minnesota, makes two round trips to Chicago each week, and only runs his truck when he is in it. He plugs in a small electric heater to keep the engine warm at home in the winter, but he still does occasionally have trouble starting the truck. He idles his truck for fewer than 1,000 h/yr. In between these extremes, an Iowa contract fleet owner reports that his drivers run their trucks all the time during the week, but the trucks are turned off for the

\footnotetext{
${ }^{1}$ Eighty-five winter days at $10 \mathrm{~h} / \mathrm{d}$ and 218 nonwinter days at $4.5 \mathrm{~h} / \mathrm{d}$.
} 


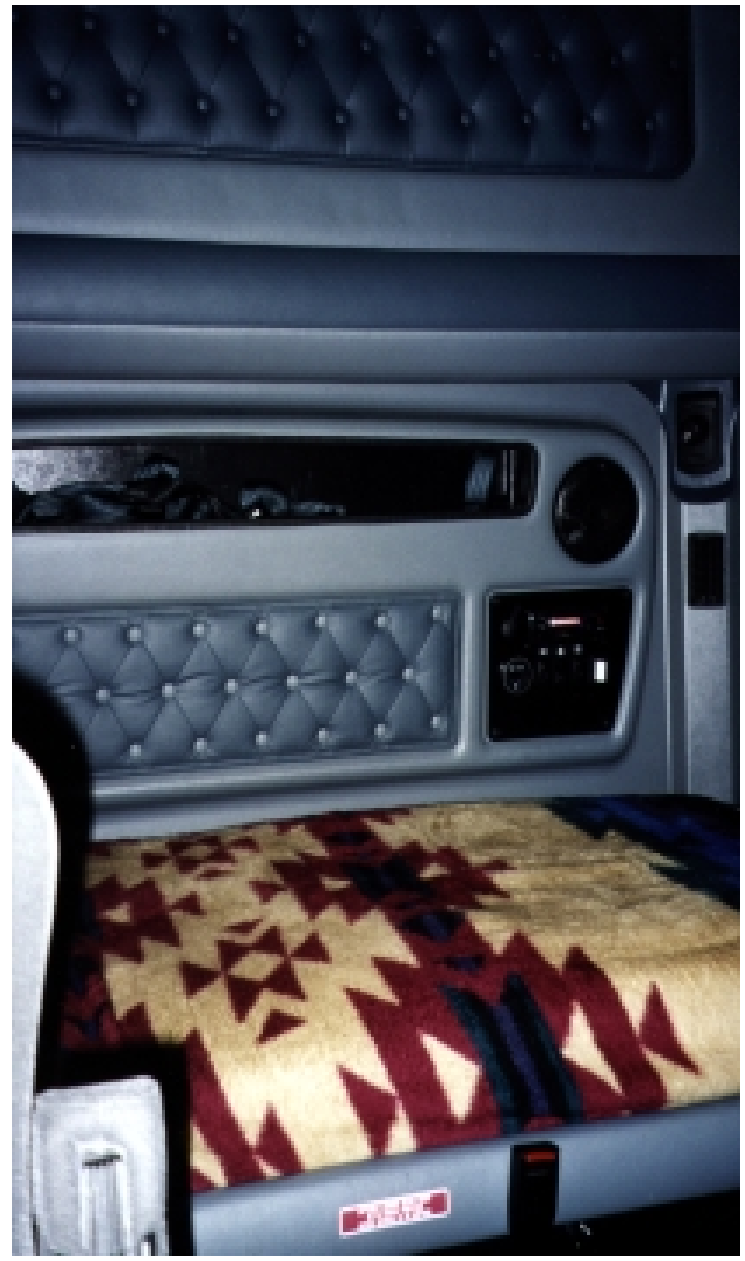

Figure 2 Typical Sleeper weekend in his yard (Riemer 1999). These 40 trucks are idling for approximately $3,600 \mathrm{~h}$ annually. In the absence of actual statistical data, we present results as a function of number of hours idled per year. Table 1 shows estimates for total numbers of long-haul truckhours idling annually in the United States.

The location and the availability of appropriate places to stop also influence truck idling patterns. Truck drivers stop to rest at public rest areas and private truck stops (TRI 1996). Most truck drivers use free public rest areas during the day and for short stops. Nearly 1,500 public rest areas are scattered throughout the contiguous 48 states and the District of Columbia, offering some 25,000 truck parking spaces for the nearly 480,000 long-distance trucks (including those that do not need to park overnight on the road). Accessibility is an important concern, which favors the public rest areas on interstate routes. Therefore, the public facilities along the busy interstate routes (such as I-5, I-10, I-40, I-80, I-90, and I-95) become full early (TRI 1996). Private truck stops provide approximately 184,000 additional parking spaces, and many truck drivers use these, with new construction projected to increase that number to 213,000 by the end of 1999 (TRI 1996). Although many trucker drivers prefer not to pay user fees, higher fuel taxes, or higher registration fees for parking, truck stops offer such services as showers, laundry, and restaurants (TRI 1996). The truck stops along the busy interstate routes report 90\% occupancy levels. Drivers sometimes park at their customers' lots if the site is safe. Drivers must balance their concerns for safety and cost in selecting a place to rest.

If there are 458,000 truck drivers who are likely to need to stop and sleep, and there are only about 210,000 parking spaces at rest areas and truck stops, then a maximum of $46 \%$ of the heavy long-haul trucks can be using them at any one time. Although trucks are out of service part of the time for maintenance, there is peak utilization on weekdays, which increases the overcrowding. Many truckers drive at night and sleep during the day. 
Table 1 Estimated Idling Hours for Long-Haul Trucks

\begin{tabular}{|ccc|}
$\begin{array}{c}\text { Average } \\
\text { Hours per Day }\end{array}$ & $\begin{array}{c}\text { Hours per } \\
\text { Year }\end{array}$ & $\begin{array}{c}\text { Truck-Hours } \\
\text { per Year } \\
\text { (millions) }\end{array}$ \\
\hline 3.3 & 1,000 & 458 \\
6 (base case) & 1,830 & 838 \\
9.9 & 3,000 & 1,374 \\
16.5 & 5,000 & 2,290 \\
\hline
\end{tabular}


$\Delta$ 


\title{
Section 3 \\ Technology Options to Reduce Idling
}

\begin{abstract}
Although idling patterns could be changed via regulation or other incentives to change behavior, these options are not considered here. Several technological alternatives could be used anywhere to displace diesel engine idling and provide truck heating and cooling. ${ }^{2}$ These options include (1) direct-fired heaters (heating only), (2) thermal storage systems, and (3) auxiliary power units (APUs). In addition, electrification of truck stops to provide parked vehicles with electricity for heating, cooling, and other purposes has been proposed (EEI 1996), but that option is not commercial. Each technology is at a different level of maturity, and each technology has a number of variations. (Table 2 summarizes the technology options and the benefits and drawbacks of each.) Although several manufacturers are mentioned in this section, our equipment survey was by no means complete, and no operational tests were performed. Therefore, no endorsements are to be inferred. The units described here are generally suitable for retrofitting on an operating truck. Some are already available as factory options on new trucks as well.
\end{abstract}

Direct-fired heaters can be used to heat both the cab/sleeper and engine or just one or the other (see Figure 3). Units are commercially available from a number of manufacturers. One of the largest suppliers in North America is Espar Heater Systems, the parent company of which, Eberspächer, has been in the business making heaters for vehicles since the 1930s (Eberspächer 1990). Espar's first direct-fired heater was developed in the early 1950s. Another company, Webasto, also makes several models for trucks and buses. Direct-fired heaters use much less fuel than the diesel engine to provide heating because they supply heat directly from a combustion flame to a small heat exchanger. The diesel engine must first burn fuel to overcome engine friction, and only part of the waste heat from the engine is transferred to the heating system.

The market share of direct-fired heaters is relatively low because of safety concerns, retrofitting costs, and unknown reliability (Whiteside 1996). For example, during cold weather, some truck drivers express concern about drain on the battery by the heater. Although this concern does not appear to be valid, the Detroit Diesel Corporation (DDC) markets an electronically controlled optimized idling device that monitors engine temperature and battery voltage and automatically starts and stops the engine when necessary to maintain battery charge or to keep engine temperatures from dropping so low that starting might be difficult. However, noise from engine starting and stopping, using such devices, was reported to wake up sleeping drivers (Riemer 1999). A gradual start/stop has been proposed to alleviate this concern. DDC also markets an optional thermostat to monitor the temperature in the cab/sleeper (DDC 1995).

2 We do not consider timers because they are designed to manage engine operation rather than provide heating and cooling. 
Table 2 Technology Options for Reducing Overnight Diesel Engine Idlinga

\begin{tabular}{|c|c|c|c|c|}
\hline Technology & Function & Benefits & Drawbacks & $\begin{array}{l}\text { Technology } \\
\text { Status }\end{array}$ \\
\hline Direct-fired heater & $\begin{array}{l}\text { Heating for } \\
\text { cab/sleeper and/or } \\
\text { engine. }\end{array}$ & $\begin{array}{l}\text { Can be used at any stop } \\
\text { for heating. Small and } \\
\text { lightweight. }\end{array}$ & $\begin{array}{l}\text { Cannot provide cooling. } \\
\text { Requires battery power } \\
\text { and may be unreliable } \\
\text { when not equipped with } \\
\text { automatic engine starting. }\end{array}$ & Commercial. \\
\hline Auxiliary power unit & $\begin{array}{l}\text { Heating and air- } \\
\text { conditioning of } \\
\text { cab/sleeper, heat } \\
\text { for engine, and } \\
\text { power for } \\
\text { auxiliaries. }\end{array}$ & $\begin{array}{l}\text { Can be used at any stop } \\
\text { for heating, cooling, and } \\
\text { auxiliaries. Recovers } \\
\text { waste heat for space } \\
\text { heating. Serves as } \\
\text { survival system. }\end{array}$ & $\begin{array}{l}\text { Heavier and larger than } \\
\text { direct-fired heater. May } \\
\text { require separate sleeper } \\
\text { air conditioner. }\end{array}$ & Commercial. \\
\hline Thermal storage & $\begin{array}{l}\text { Heating and air- } \\
\text { conditioning for } \\
\text { cab/sleeper only. }\end{array}$ & Driver comfort. & $\begin{array}{l}\text { Does not heat engine. } \\
\text { Requires relatively large } \\
\text { space for storage medium. } \\
\text { Performance dependent } \\
\text { on truck use. }\end{array}$ & $\begin{array}{l}\text { At or near- } \\
\text { commercial. } \\
\text { Commercial in other } \\
\text { applications. }\end{array}$ \\
\hline $\begin{array}{l}\text { Direct heat with thermal } \\
\text { storage cooling }\end{array}$ & $\begin{array}{l}\text { Heating and air- } \\
\text { conditioning of } \\
\text { cab/sleeper and } \\
\text { heat for engine. }\end{array}$ & $\begin{array}{l}\text { Can be used at any stop } \\
\text { for heating and cooling. }\end{array}$ & Requires battery power. & Commercial. \\
\hline Truck stop electrification & $\begin{array}{l}\text { Provides electricity } \\
\text { for heating, air- } \\
\text { conditioning, and } \\
\text { auxiliaries. }\end{array}$ & $\begin{array}{l}\text { Provides power for heating } \\
\text { and cooling and } \\
\text { auxiliaries. }\end{array}$ & $\begin{array}{l}\text { Limited choice of over- } \\
\text { night location. Requires } \\
\text { separate sleeper air } \\
\text { conditioner and electrically } \\
\text { powered heater. Requires } \\
\text { infrastructure at the truck } \\
\text { stop. }\end{array}$ & $\begin{array}{l}\text { Not commercial. } \\
\text { Commercial in other } \\
\text { applications. }\end{array}$ \\
\hline
\end{tabular}

a Excludes timer devices.

b A thermoelectric device is being developed by Hi-Z Technology that promises to reduce the need for battery power (HiZ 1996).

References: Direct-fired heater: Espar (undated); Thermal storage: PCG (1995).

In addition, thermoelectric devices that reduce the battery power needed by direct-fired heaters are in the research and development stage (HiZ 1996). HiZ Technology proposes to modify its current-production $14-\mathrm{W}$ and $24-\mathrm{W}$ units for operation on direct-fired heaters. Thermoelectric devices convert heat directly to electricity. They would be installed on the hot end of the direct-fired heaters and provide some power for the cab/sleeper heater. However, thermoelectric devices are not yet commercial and do not totally eliminate battery use.

Auxiliary power units (APUs) are mounted externally on the truck cab or sleeper and consist of a small internal combustion engine (usually diesel) equipped with a generator and heat recovery to provide electricity and heat (see Figure 4). For air-conditioning, an electrically powered air-conditioner unit is normally installed in the sleeper area, although some units use the 


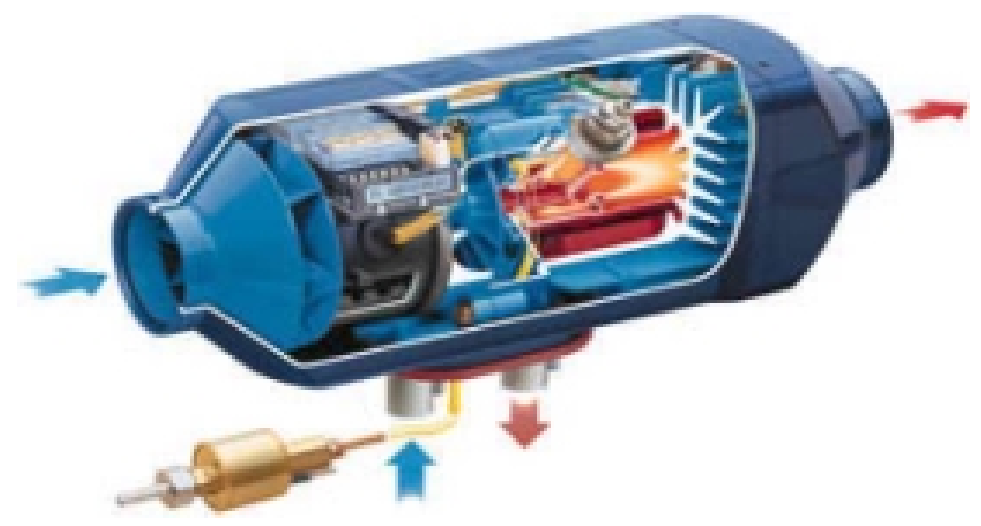

Figure 3 Espar Heater (Courtesy of Espar Heater Systems)

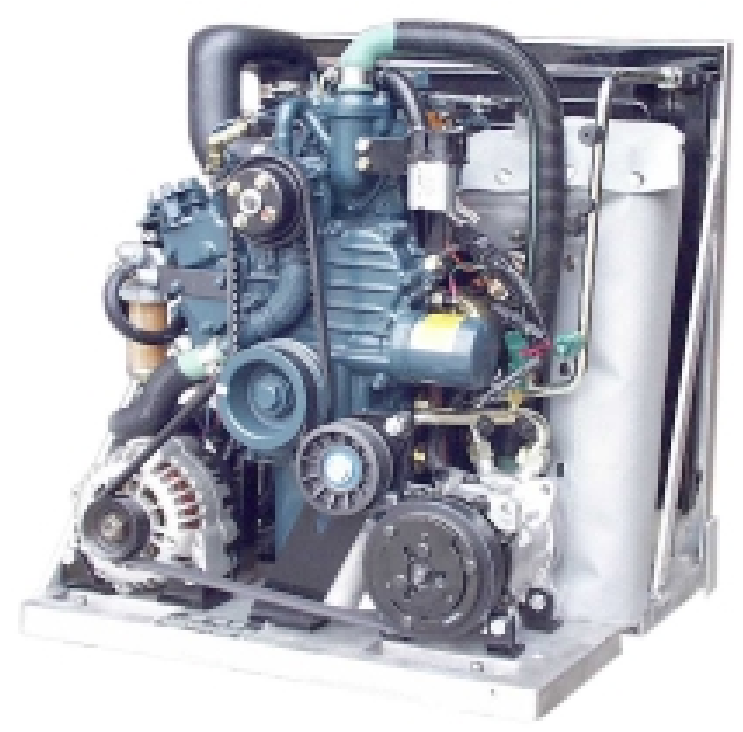

Figure 4 Pony Pack Auxiliary Power Unit (Reproduced with permission, Pony Pack, Inc.)

and engine coolant warm and cools the cabin, so drivers avoid start-up problems. Manufacturer's data on energy consumption and costs for this APU are presented in Appendix A. Actual test data will be collected from a demonstration fleet of about 10 trucks in Texas (MSR 1999). One advantage cited for APUs is that they can serve as survival systems in case of truck breakdown in extreme weather conditions.

In the future, it might be possible to use a gasoline or diesel-powered solid oxide fuel cell (SOFC) as the power source in an APU. BMW is currently doing research on an SOFC to replace a car's battery and alternator (Neff 1999). DOE's Office of Transportation Technologies is investigating the feasibility of an SOFC as an APU in trucks. No data are available at this early concept stage. 
Thermal storage systems (TESs) for trucks are relatively new. A TES consists of a phasechange material that stores heating or cooling energy that is transferred from the vehicle engine or air-conditioning while the vehicle is operating (PCG 1995). One company, SHAPE Energy Resources (Store Heat and Produce Energy, Inc.), offered systems with thermal tank capacities from 16 to 35 gal, which allow heat storage capacities of up to about 23,000 Btu.

SHAPE Energy Resources is now out of business. With TESs, heating and cooling, but no electrical power, can be supplied to the sleeper compartment (only) for up to $8 \mathrm{~h}$ while the cab is allowed to cool off or heat up. A small amount of electrical power is required. TESs are large compared with the direct-fired heaters (which only supply heat), but they are similar in size to APUs. These units have been tested by several large trucking companies, including Schneider and Dart Transit, and have been evaluated by Peterbilt and others as factory options (SHAPE 1997). The effectiveness of TESs depends on the duty cycle of the truck, which could be a disadvantage under certain conditions (for example, if the air conditioner was not used during the day, the TES could not cool the sleeper overnight). Limited cost and performance data are available for this technology. The Thermocooler, a variant offered by Webasto (see Figure 5),

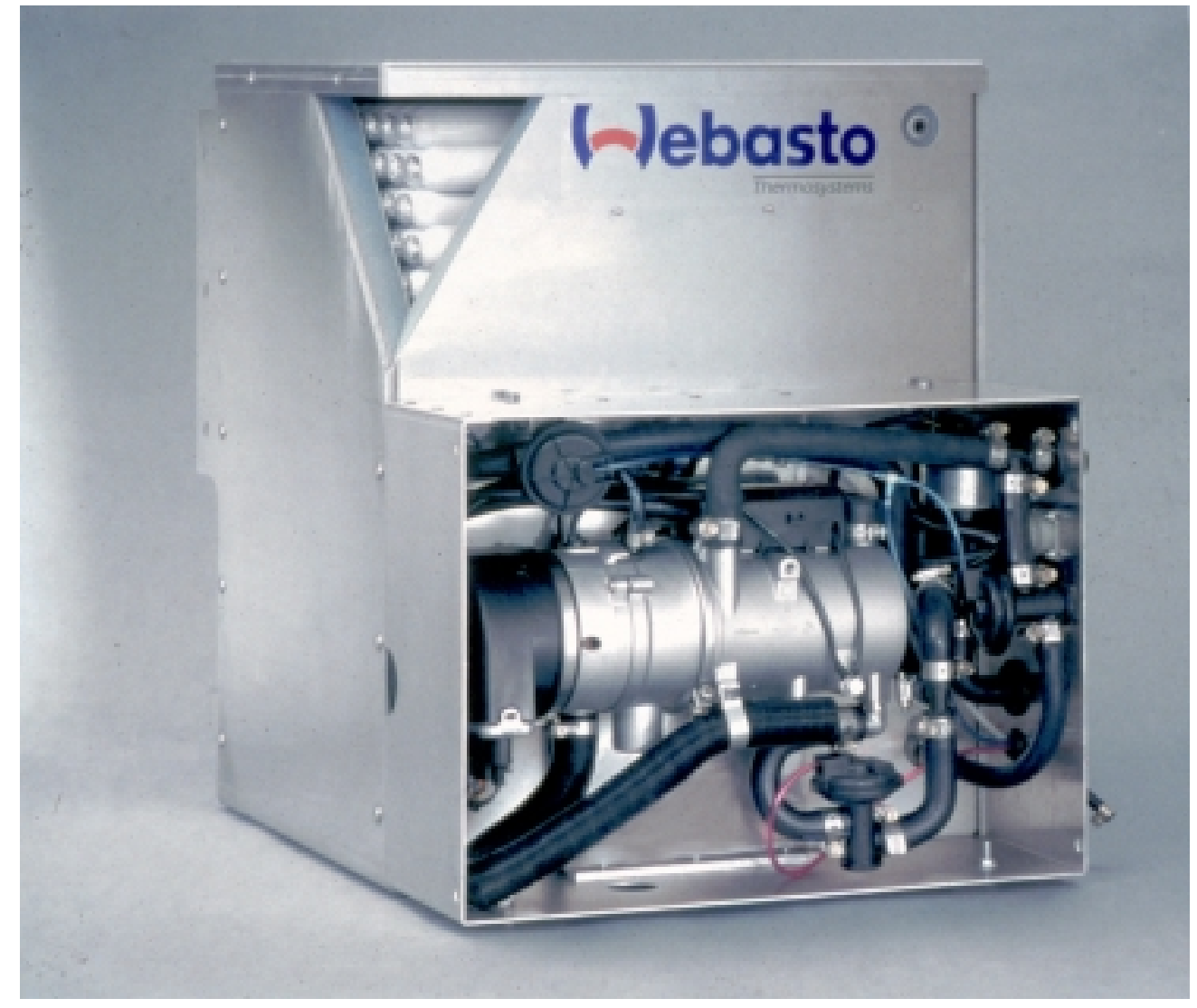

\footnotetext{
Figure 5 Webasto Thermocooler ${ }^{\circledR}$, Auxiliary Climate Control System (Reproduced with permission, Webasto Thermosystems, Inc., Lapeer, Michigan)
} 
combines a direct-fired heater with a thermal storage unit for cooling and is claimed to have sufficient heat to keep both the engine and the cab/sleeper warm (Webasto 1999).

Truck stop electrification is another option for reducing truck idling. The trucker would simply "plug in" the truck to outlets at the truck stop to power heaters, air conditioners, marker lights, and accessories like microwave ovens and refrigerators. Electrification involves modifying the truck stop as well as the truck. Currently, there are no truck stops that provide plug-in power for truck and other heavy-vehicle needs, but a pilot test is planned as part of the Texas Clean Cities program (MSR 1999). Also, the South Coast Air Quality Management District (SCAQMD) has a program for truck stop operators to generate mobile source emission reduction credits by providing electrification for trucks (SCAQMD 1997).

Electrification involves the installation at truck stops of ground electric outlets (or plates in case of induction) at each parking space. It also involves retrofitting trucks with an electric engine block heater, an electric fuel heater, an electric heating/cooling device for cab and sleeper conditioning, and electric automatic idle control. A relay to bypass the battery and activate the cab's electric system is also included. Provisions for buses and electric vehicles are also possible. Truckers will not install the necessary equipment when there is no place to plug it in, and truck stop owners will not install infrastructure when nobody has the equipment to use it. Volvo is reported to offer an electrification option on new trucks (employing AC power systems) (T-SEA 1998), and Freightliner will soon as well. In addition, Volvo has purchased an interest in a chain of truck stops (Tempchin 1999), which they might electrify.

As part of engine manufacturers' efforts to reduce parasitic power in their products, they are replacing shaft-driven pumps and accessories with electrically driven devices. Electrically driven pumps and compressors, such as those marketed by Sandon International, can be operated only on demand, thereby reducing the overall parasitic load on the engine (Brooks 1999). The industry envisions that the "electrified" truck will be capable of being plugged into outlets at the truck stop. Specific Climate Systems (SCS/Frigette) produces several types of 110-V, electrically driven cooling and heating systems that can be either be plugged in or operated by the engine's alternator. SCS/Frigette also produces deep-cycle battery packs that provide $864 \mathrm{Ah}$, which would provide an estimated $8 \mathrm{~h}$ of air-conditioning or heating (Pannell 1999). 
$\Delta$ 


\section{Section 4 \\ Potential Implications of New Technologies}

\subsection{Reduced Energy Use}

Fuel consumption is reduced by eliminating unnecessary engine idling. Table 3 provides data on (1) the energy used during engine idling when providing heating and (2) the energy required for several alternatives to idling, including truck stop electrification. Note that the heater and storage systems are not directly comparable with the other alternatives because they do not provide the full range of services. Appendix B contains more detailed information about emissions data, while Appendix A provides equipment and emissions data. About 10,650 Btu/h is needed to keep the engine warm, which is done by warming the coolant, and an additional $\sim 4,100 \mathrm{Btu} / \mathrm{h}$ is needed to provide cab/sleeper heating. Heating can be supplied by circulating the coolant if it is being warmed or by providing a separate air heater. (The engine requires more heat because it is not insulated.) These requirements are based on medium settings for the Espar heating system. More heat is provided at higher settings with additional fuel consumption; other units have similar capacities. Energy requirements can be reduced by better insulating the truck and by using sunshades during daytime stops. Insufficient data were available to do a complete analysis of cooling systems; therefore, most of the discussion here focuses on heating.

The idling fuel-use rate varies, depending on equipment load and engine speed. To avoid engine wear due to low-speed idling, most truckers idle their engines at 1,000 rpm with some load. The Truck Maintenance Council (TMC) suggests fuel flow rates for various loads and engine speeds in its Recommended Practice Bulletin 1108. Diesel engine idling consumes about one gallon of diesel fuel per hour when the truck's heating or air-conditioning system is operated (for 5 brake horsepower load at 1,000 rpm; TMC 1995), or about 128,500 Btu/h (the newest engines consume slightly less). Note that the engine is only about $11 \%$ efficient when used to heat the cab/sleeper and the block $(14,750 \mathrm{Btu} / \mathrm{h}$ output [cab/sleeper heater plus engine block heater] divided by $128,500 \mathrm{Btu} / \mathrm{h}$ fuel consumption).

The engine provides cab and engine block heating as a by-product of producing shaft work, but a directly fired heater avoids the losses associated with the production of shaft work by simply indirectly heating the air that enters the cab/sleeper area. A typical furnace efficiency is 80-85\%. Therefore, the direct-fired heater for providing cab/sleeper and engine heat is extremely efficient compared with engine idling or electric heating. Assuming that the battery energy consumed during heater use must be supplied by the engine after restart, the energy requirement is about $18,540 \mathrm{Btu} / \mathrm{h}$, yielding an overall efficiency of $80 \%$. Efficiency of the APUs is high as well, because the engine is sized to meet electricity and heat requirements.

Data were not available to evaluate energy consumption by the storage systems. Product literature states that thermal storage units require energy $(\sim 50 \mathrm{~W})$ for operating fans and 


\section{Table 3 Estimated Cab/Sleeper Heating and Engine Block Heating Energy}

Requirements ${ }^{a}$

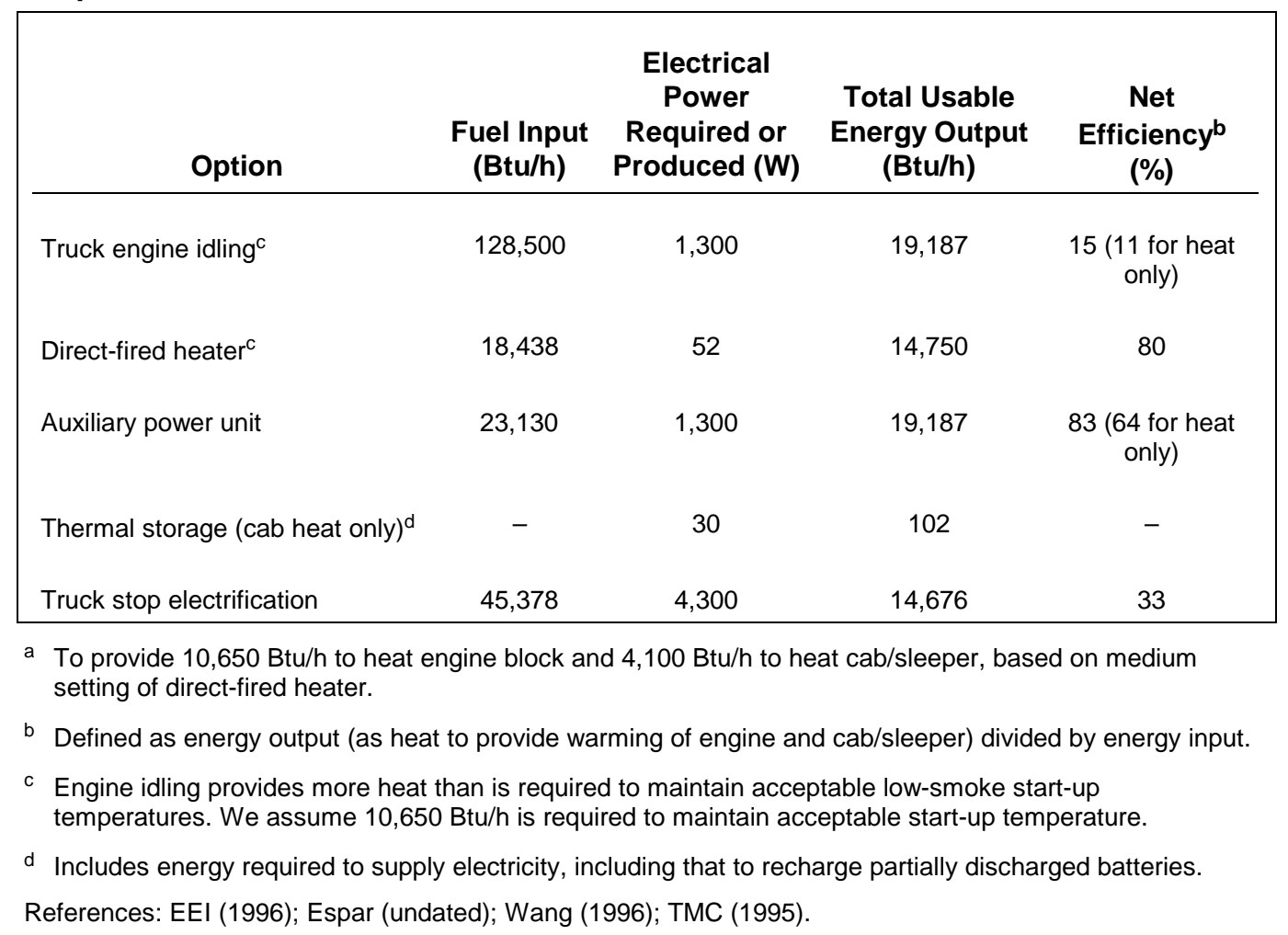

pumping the storage medium while the unit is running. Manufacturers do not provide information on the increased fuel requirements during vehicle operation to supply additional heating or cooling for the storage medium. However, Webasto estimates an increased load of $1 \mathrm{hp}$ to cool the medium (Koziel 1999). If the truck averages $200 \mathrm{hp}$ at $55 \mathrm{mph}$ and gets $6 \mathrm{mpg}$, it uses 37-55 gal of fuel during the $4-6 \mathrm{~h}$ that the medium is cooled. The marginal cooling load adds about $0.5 \%(1 / 200)$ to that, or $0.19-0.28$ gal. This is the fuel used for $8 \mathrm{~h}$ of cooling, so the fuel use is approximately $0.023-0.034 \mathrm{gal} / \mathrm{h}$ of cooling.

One drawback of the direct-fired heater and storage options is that they need electrical power, and so truckers are concerned that they will not have enough battery capacity to restart the engine, especially during cold weather (Jessiman 1996). During a typical overnight heating cycle of $8 \mathrm{~h}$, at a current draw of $1.9 \mathrm{~A}$, a cab/sleeper heater requires about $15 \mathrm{Ah}$ of battery capacity (Espar undated). The engine block heater requires power for the coolant circulating pump; about $3 \mathrm{~A}$ is required for this unit on the medium setting (5.8 A on high), and so about $24 \mathrm{Ah}$ of battery capacity is required overnight on the medium setting (46 Ah on high). A total battery capacity of $39 \mathrm{Ah}$ is therefore required on the medium setting (61 on high). The typical truck has three $12-\mathrm{V}$ batteries with a total capacity of $150 \mathrm{Ah}$, and engine start-up requires about $60 \mathrm{Ah}$. Under most conditions, sufficient battery capacity would therefore remain for start-up. In addition, thermoelectric converters for direct-fired heaters promise to reduce electrical power 
requirements (Hi-Z 1996). A 12-W unit could provide approximately $8 \mathrm{Ah}$, but it would not totally eliminate the need for battery power.

The results of a literature review of APUs suggest that about 23,000-40,000 Btu/h of primary energy is required for heating and cooling, which is considerably less energy than the 128,500 Btu/h used when the truck idles (ATC undated a; ATC undated b; Greer 1999).

If electrical power supplies the energy for cab/sleeper heating and engine block heating, about $4.3 \mathrm{~kW}$ is required to supply the assumed $14,750 \mathrm{Btu} / \mathrm{h}$ requirement. The primary energy consumed at the power plant is $45,378 \mathrm{Btu} / \mathrm{h}$, assuming a conversion efficiency of $32.5 \%$. Note that very little of the primary energy used to generate electricity is in the form of petroleum, so electrification minimizes oil use.

\subsection{Emissions Reductions}

Using more efficient alternatives to diesel engine idling also reduces emissions. Estimated emissions for current practice and alternatives are listed in Table 4. No data are available for storage options, which produce no emissions during their operation, but they are expected to cause a small increase in truck operating emissions because of increased load on the heating, ventilation, and air-conditioning (HVAC) system to heat or cool the thermal storage medium. The data on equipment were provided by the suppliers and should be considered preliminary. Emissions of carbon dioxide were calculated on the basis of the fuel input. Emissions from electricity generation are based on the current average U.S. generation mix. Emissions would differ somewhat by region or time of day (truck drivers sleeping at truck stops at night would be using off-peak power, which removes gas and oil from the generating mix). Further, more detailed work could examine the implications of changing the generating mix. With the caveat that additional, more reliable data are needed, we can make some tentative observations.

Truck engine idling produces significantly higher greenhouse gas $\left(\mathrm{CO}_{2}\right)$ emissions than any of the other options considered (because of its higher energy use) and, in almost all cases, emits more of all pollutants. The direct-fired heater and auxiliary power units generate significantly less $\mathrm{CO}_{2}$ than electricity use, assuming heating loads in each case are equal. Compared with idling, electricity use significantly reduces all of the emissions tabulated (except possibly $\mathrm{SO}_{2}$; see Appendix B) for the current U.S. generation mix. Electricity use reduces particulate emissions compared with all of the other options for which data were available. These findings are clear.

However, conclusions about any of the other emissions from onboard units are highly speculative because of the uncertainty in the data reported. The direct-fired heater and APU may produce more hydrocarbons than electrification because emissions are relatively high during start-up and as the heater warms up. Although reported emissions from APUs were significantly higher for THC (total hydrocarbons), $\mathrm{CO}$ (carbon monoxide), $\mathrm{NO}_{\mathrm{x}}$ (nitrogen oxides), and particulates than those from the direct-fired heater, both sets of data are suspect. Therefore, these numbers should not be used to support one type of equipment over another. 
Table 4 Estimated Emissions from Truck Cab/Sleeper and Engine Block Heating $(g / h)^{a}$

\begin{tabular}{|c|c|c|c|c|c|}
\hline \multirow[b]{2}{*}{ Technology } & \multicolumn{5}{|c|}{ Emission } \\
\hline & VOC or THC b & $\mathrm{CO}$ & $\mathrm{NO}_{\mathrm{x}}$ & $\mathrm{PM}_{10}{ }^{\mathrm{C}}$ & $\mathrm{CO}_{2}$ \\
\hline Idling ${ }^{d}$ & 12.6 & 94.6 & 56.7 & 2.57 & 10,397 \\
\hline Direct-fired heater ${ }^{\mathrm{e}}$ & 0.174 & 0.437 & 0.264 & $\mathrm{n} / \mathrm{i}^{\mathrm{f}}$ & $\begin{array}{l}1,456 \\
\text { (calc.) }\end{array}$ \\
\hline Thermal storage ${ }^{g}$ & $\mathrm{n} / \mathrm{i}^{\mathrm{f}}$ & $\mathrm{n} / \mathrm{i}^{\mathrm{f}}$ & 4.0 & 0.10 & $\begin{array}{c}356 \\
\text { (calc.) }\end{array}$ \\
\hline Auxiliary power unit ${ }^{\mathrm{h}}$ & 0.45 & 7.5 & 11.6 & 0.69 & $\begin{array}{l}1,871 \\
\text { (calc.) }\end{array}$ \\
\hline Electrification ${ }^{\mathrm{i}}$ & 0.054 & 0.481 & 6.04 & 0.035 & 3,014 \\
\hline \multicolumn{6}{|c|}{ a Data are not comparable; accuracy in doubt. } \\
\hline \multicolumn{6}{|c|}{ b Volatile Organic Compounds or total hydrocarbons. } \\
\hline \multicolumn{6}{|c|}{ c Particulate matter with Sauter mean diameter of $10 \mu \mathrm{m}$ and less. } \\
\hline \multicolumn{6}{|l|}{ d ATA (1998). } \\
\hline \multicolumn{6}{|c|}{$\begin{array}{l}\text { Espar (1993). From combustion of fuel in the heaters only; excludes combustion of additional } \\
\text { fuel to recharge battery because the amount of fuel used is negligible ( } 584 \mathrm{Btu} / \mathrm{h} \text {, or } 0.036 \mathrm{gal} \\
\text { over an 8-h cycle). Accuracy in doubt. }\end{array}$} \\
\hline \multicolumn{6}{|l|}{$\mathrm{f} n / \mathrm{i}=$ no information. } \\
\hline \multicolumn{6}{|c|}{$\begin{array}{l}\text { g Assumes } 5 \mathrm{hp}-\mathrm{h} \text { required to charge the system for } 8 \mathrm{~h} \text { of cooling under full engine load, at a } \\
\text { fuel consumption rate of } 169 \mathrm{~g} / \mathrm{bhph} \text { (brake horsepower per hour; calculated on the basis of } \\
\text { average model-year } 1996 \text { weight-class } 8 \mathrm{~B} \text { truck-specific fuel consumption [EPA 1998]). } \mathrm{NO}_{\mathrm{x}} \\
\text { and PM emitted at the 1998-2003 model-year-regulated rate of } 4 \mathrm{~g} / \mathrm{bhph} \mathrm{NO}_{\mathrm{x}} \text { and } \\
0.10 \mathrm{~g} / \mathrm{bhph} \mathrm{PM}_{10} \text { (EPA 1997). }\end{array}$} \\
\hline \multicolumn{6}{|c|}{ h Pony Pack 104, winter operation. Data from Pony Pack, Inc. (undated). } \\
\hline \multicolumn{6}{|c|}{ i Providing 4.3 kW to truck heaters. Emissions data from Wang (1999) and DOE (1993). } \\
\hline
\end{tabular}

\subsection{Cost Analysis}

Cost estimates for several of the technology options were available, and these allow us to do a simple economic analysis of the options available to reduce overnight idling. Equipment costs range from about $\$ 1,400$ installed for a small cab heater to more than $\$ 7,000$ for an APU with an inverter to allow use of $110-\mathrm{V}$ appliances. Truck owners could be deterred by the high initial cost of some of the units, especially the APUs. However, to alleviate this concern, some equipment manufacturers offer their units for lease, with the option to buy after three years. The capital cost for the infrastructure for truck electrification is also high and could not be alleviated by leasing arrangements. ${ }^{3}$ Another economic concern is the weight of the units that supply cooling. Although carrying this extra weight would make a negligible difference in the vehicle's fuel economy ( $\sim 300 \mathrm{lb}$ out of $80,000 \mathrm{lb}$ is less than $0.4 \%)$, it would reduce the load that could be carried for trucks that are weight-limited (weight out before they cube out). The extra weight

3 A report by the Truck Research Institute (TRI 1996) suggests a cost of \$256-341 million for an increase of 15,032 spaces in the top-10 critical corridors, or about $\$ 17,000-22,700$ per space. 
could reduce revenues by as much as $0.6 \%$. For trucks that are volume-limited ("cube out"), there would be no such penalty.

If idling uses $1 \mathrm{gal} / \mathrm{h}$ of diesel fuel and an alternative uses only $0.20 \mathrm{gal} / \mathrm{h}$, at the current price of about $\$ 1.75 / \mathrm{gal}$, the immediate savings in operating cost is $\$ 1.40 / \mathrm{h}$, for an annual dollar savings equal to the number of idling hours avoided per year times 1.4. If there were no other savings, a $\$ 6,000$ unit would then have a 17 -month payback time, if 3,000 hours of idling were avoided per year. But fuel savings are not the only cost savings attributable to the reduction of truck idling. Idling causes engine wear, and reducing idling allows an increase in the interval between expensive oil changes and lengthens the actual mileage traveled before a truck engine is likely to need an overhaul. The Truck Maintenance Council (TMC) published a bulletin to enable estimation of the monetary value of these increases. Using the TMC's method, we estimate approximately $\$ 0.07$ savings on preventive maintenance (oil changes) and $\$ 0.07$ savings by increasing the time until overhaul, per hour of idling avoided. These savings are relatively small, but not insignificant. ${ }^{4}$

The issue of payback time is an important consideration when examining equipment purchases. The ATA (1997) has reported that truck owners are only interested in items with a payback time of under two years. One reason for that is the rapid replacement rates in fleet trucks. Because reliability is considered so critical, a typical small-fleet owner replaces his or her trucks every three to four years, which is around the time when warranties expire. In addition, if all trucks are under warranty, the fleet operation is simplified because the owner does not need a complete maintenance shop. Larger fleets may be replaced even more often (every two to three years); taking advantage of volume discounts offered by dealers. With such rapid fleet turnover, factory-installed units, which are likely to be available at lower cost, could be a more promising market than retrofits. Retrofits might be attractive for owner-operators who keep their trucks longer, but small operators often follow larger ones in adoption of any innovation (Riemer 1999).

A simple economic analysis of several options to reduce truck idling is presented in Table 5, with payback time estimated as a function of hours idled per year, on the basis of the expected fuel costs for each unit. Savings from reduced maintenance and wear are included. Using this table requires some caveats. First, as with the emissions data, some of the numbers are projected because there is no real experience with these options. For instance, the cost for thermal storage is a target that has not been achieved, and the electrification costs are quite uncertain. Second, heaters and APUs from different manufacturers have different costs and energy requirements. Third, the cost of additional fuel to operate the truck on the road if the thermal storage medium must be heated or cooled has not been included because it is unknown. And finally, for the units that supply heating only, the number of idling hours includes those occurring during the winter

4 Note that previous estimates of maintenance savings were considerably higher. The difference is in the number of miles to which one hour of idling is equivalent. The TMC bulletin assesses engine wear proportional to fuel consumed, so $1 \mathrm{~h}$ of idling $=7 \mathrm{mi}$ if the truck gets $7 \mathrm{mpg}$ on the road. Older estimates equated $1 \mathrm{~h}$ to $80 \mathrm{mi}$, which is twice the wear per hour as driving. Reduction in fuel sulfur (which caused significant damage to the engine) and change in idling revolutions per minute both contributed to the change. 
Table 5 Economic Analysis of Equipment Options, as Function of Idling Hours Displaced

\begin{tabular}{|c|c|c|c|c|}
\hline \multirow[b]{2}{*}{ Technology } & \multirow[b]{2}{*}{ Model } & \multirow[b]{2}{*}{ Cost (\$) } & \multicolumn{2}{|c|}{ Payback (yr) ${ }^{a}$} \\
\hline & & & $@ 1,000$ h & $@ 3,000 \mathrm{~h}$ \\
\hline Direct-fired heater & $\mathrm{D} 5 \mathrm{~W}+\mathrm{D} 1 \mathrm{~L}-\mathrm{C}$ & $3,200^{\mathrm{b}}$ & 1.8 & 0.60 \\
\hline Thermal storage & & $2,700^{c}$ & 1.4 & 0.45 \\
\hline Direct heat with storage cooling & Thermocooler & $4,200^{d}$ & 2.7 & 0.93 \\
\hline Auxiliary power unit & Power Pak & $7,095^{\mathrm{e}}$ & 4.3 & 1.4 \\
\hline Electrification & Unspecified & $1,700+2,500 /$ spot & 2.7 & 0.93 \\
\hline
\end{tabular}

a $\$ 1.75 /$ gal diesel fuel.

b Jessiman (1996).

c Estimate from SHAPE (1997).

d Webasto (1999). Payback calculated assuming 59\% of operation heating and $41 \%$ cooling. Increased fuel use during operation not known or included.

e IPS literature.

only. For the units that supply cooling as well, all of the idling hours can be displaced, resulting in a faster payback. With these caveats in mind, we can conclude that options that supply electricity as well are economically viable for trucks that are idled for 1,000-3,000 or more hours a year, while the heater units could be used across the board. Payback times for fleets, which would receive quantity discounts on the prices, would be somewhat shorter.

Note that the cost for electrification includes an estimated $\$ 0.08 / \mathrm{kW}$ to pay for the power used, and the payback time is calculated by assuming that only one truck can use each spot per day. However, if occupancy were increased to two - one sleeping at night and the other during the day — the payback time would be reduced to $1.9 \mathrm{yr}$ for $1,000 \mathrm{~h} / \mathrm{yr}$ idling and to $0.6 \mathrm{yr}$ for $3,000 \mathrm{~h}$. 


\section{Section 5 \\ Conclusions}

\subsection{National Benefits}

By using an idling fuel-consumption rate of $1 \mathrm{gal} / \mathrm{h}$, the estimated annual overnight idling fuel use (in gallons) is equal to the number of truck idling hours, as shown in the last column in Table 1. Long-haul trucks idling overnight consume more than 838 million gallons of fuel (20 million barrels) annually (base-case estimate). Using alternatives to overnight idling could save much of this fuel and reduce emissions and operation costs. Short-distance trucks and other heavy-duty vehicles (such as transit buses, intercity buses, school buses, and railroad locomotives) also idle for various reasons. If these vehicles are included, the estimated fuel consumption due to idling climbs to 3.2 billion gallons (76 million barrels) annually. ${ }^{5}$ However, most of this usage could not be avoided by using the technologies discussed in this report.

Table 6 summarizes the energy use and $\mathrm{CO}_{2}$ emissions impact for each option over the entire year (heating and cooling). This baseline estimate assumes that the direct-fired heaters are operated $10 \mathrm{~h} / \mathrm{d}$ in the winter and that idling is used to provide cab/sleeper cooling for $4.5 \mathrm{~h} / \mathrm{d}$ in the summer, with $100 \%$ market penetration in the eligible class 7 and class 8 trucks, for each technology. It represents the upper bound on energy savings benefits for the assumed number of idling hours - actual benefits of each alternative to idling would be lower for lower rates of market penetration. In particular, note that electrification impacts are estimated by assuming that all trucks could use electrified stops, and so all trucks and parking spaces would have to be electrified and the spaces would have to be used by an average of 1.5 trucks per day (because there are more trucks than parking spaces). Both scenarios are unlikely. Actual impacts would, of course, depend on the actual number of idling hours. A survey should be undertaken to estimate actual current idling patterns in the United States.

Several conclusions can be drawn on the basis of the information in this table. First, any of the listed alternatives has significant potential to reduce all impacts compared to idling overnight. Even the direct-fired heater, which is only assumed to be used 85 days per year, reduces total energy use, petroleum use, and $\mathrm{CO}_{2}$ emissions by about $40 \%$ over the whole year and by about $85 \%$ for the period when it is used. Auxiliary power units reduce energy and petroleum use and $\mathrm{CO}_{2}$ emissions by more than $80 \%$ for the entire year. Electrification could achieve almost $70 \%$ energy savings, reduce $\mathrm{CO}_{2}$ emissions by $74 \%$, and reduce $\mathrm{CO}$ emissions and petroleum use by more than $99 \%$. Energy storage options are also expected to significantly reduce idling impacts. Data are considered too preliminary to make conclusions about the relative potential to reduce the emissions. Most pollutants are reduced by using energy-saving alternatives to idling.

\footnotetext{
${ }^{5}$ Data are not available on fuel consumed by off-highway vehicles during idling.
} 


\section{Table 6 Baseline Annual Heating/Cooling Energy Use and $\mathrm{CO}_{2}$ Emissions for $100 \%$ Market Penetration by Alternative Technologies $^{a}$}

\begin{tabular}{|c|c|c|c|}
\hline Technology & $\begin{array}{c}\text { Energy Usage } \\
\left(10^{12} \mathrm{Btu}\right)\end{array}$ & $\begin{array}{l}\text { Petroleum } \\
\text { (10 } 10^{3} \text { gal) }\end{array}$ & $\begin{array}{c}\mathrm{CO}_{2} \\
\text { Emissions } \\
\left(10^{3} \text { tons }\right)\end{array}$ \\
\hline Truck engine idling & 107.5 & 838,140 & 9,597 \\
\hline Direct-fired heater plus idle cooling & 64.7 & 504,433 & 5,764 \\
\hline $\begin{array}{l}\text { Direct-fired heater plus thermal } \\
\text { storage cooling }\end{array}$ & 10.2 & 79,197 & 907 \\
\hline Auxiliary power unit & 19.3 & 150,860 & 1,727 \\
\hline Truck stop electrification & 34.2 & 2,127 & 2,504 \\
\hline
\end{tabular}

\subsection{Summary}

Truck engine idling consumes significant amounts of fuel to provide heating in the winter and cooling in the summer. Many fuel-efficient options are available to provide heating and cooling without resorting to idling. Promising options include (1) direct-fired heater for cab/sleeper heating, with or without storage cooling; (2) auxiliary power units; and (3) truck stop electrification. Along with truck stop electrification, electricity-based devices in the truck (for example, those supplied by SCS/Frigette) would be needed. Each option has benefits and drawbacks.

The direct-fired heater is very efficient (about $80 \%$, compared with only $11-15 \%$ for truck idling) because it simply indirectly heats the air that enters the cab/sleeper area. Net energy conversion efficiency of electrification (33\%) is lower than that of the direct-fired heater, and the market for electrification is limited to the available spaces, but a complete range of services is provided. Electrification would most likely be successful over heavily traveled routes, where a trucker could be sure of finding an electrified stop when he or she needed it. Auxiliary power units are very efficient and they provide all necessary services at any location. A drawback of direct-fired heaters is that they do not provide air-conditioning or electric power. Another drawback is that they need electrical power, and so truckers will be concerned that they will not have enough battery capacity to restart the engine, especially during cold weather. This option has had limited market penetration in the past. But direct-fired heaters are small and relatively inexpensive, and thermoelectric power-conversion devices are under development that promise to help reduce their electricity consumption.

If typical trucks average $1,830 \mathrm{~h}$ of idling annually, eliminating idling and installing and operating direct-fired heaters during winter would save about 311 million gallons 
(7.5 million bbl) of diesel fuel ( $850 \mathrm{~h} / \mathrm{yr}$, thus yielding fuel savings of $80 \%$ ), on the basis of a truck population of 458,000 . This savings is equivalent to about $0.2 \%$ of total transportation oil use and $1 \%$ of heavy truck oil use. The investment cost would be about $\$ 1$ billion, and the annual fuel savings would be approximately $\$ 544$ million (at $\$ 1.75 /$ gal diesel fuel). A maximum of about 836 million gallons (19.9 million bbl) of diesel fuel could be displaced annually if all 458,000 trucks were to use electric heating and cooling at electric truck stops (most fuels used for generation of electricity are not petroleum-based). The actual potential savings depends on the number of hours of idling displaced. Both of these technologies have other applications direct-fired heaters can be used on school buses and urban buses, as well as on trucks. Electrification can service transit buses and electric vehicles. Other technologies could also enable considerable savings.

Market acceptance of any of the options will depend primarily on the perceived benefit of the technology. The market for direct-fired heaters in new trucks is about 2\% (Jessiman 1996), current APU sales are believed to be a few hundred per year, and the market for electrification is extremely small. Therefore, market acceptance of any of these technologies would have to be augmented by appropriate government incentives. Research and development to make these devices reliable would also augment market acceptance and would encourage researchers to explore new technologies, like fuel-cell APUs. 
$\Delta$ 


\section{Section 6 References}

ATA: American Trucking Association

ATA, 1997, Return on Investment Study, ATA Survey Center for American Trucking Association, March 7.

ATA, 1998, Green Truck website, American Trucking Association, http://www.truckline.com/ air_emissions/1420.html, Oct. 5.

ATC: Advanced Thermodynamics Corporation

ATC, undated a, New Slimmer Napsac Mk II From ATC, brochure prepared by Advanced Thermodynamics Corporation, Sault Ste. Marie, Ontario, Canada.

ATC, undated b, Harvey Wallhanger ${ }^{T M}$ Truck Air Conditioning System, brochure prepared by Advanced Thermodynamics Corporation, Sault Ste. Marie, Ontario, Canada.

ATC, undated c, New A.P.U. (Auxiliary Power Unit) Type Freddy, brochure, prepared by Advanced Thermodynamics Corporation, Sault Ste. Marie, Ontario, Canada.

Brooks, R., 1999, personal communication with Rodger Brooks (Sanden International [USA], Inc., Wylie, Texas), Sept.

City of Philadelphia, 1986, Section III. Idling of Diesel Powered Motor Vehicles, Control of Emissions from Mobile Sources, Air Management Regulation IX, City of Philadelphia, Department of Public Health, Air Pollution Control Board, Philadelphia, Penn., Jan. 9.

DDC: Detroit Diesel Corporation

DDC, 1995, DDC Optimized Idle Feature Receives Nifty Fifty Award, Detroit Diesel Corporation, Detroit, Mich.

DOE: U.S. Department of Energy

DOE, 1993, Utility Emissions Associated with Electric and Hybrid Vehicle (EHV) Charging, U.S. Department of Energy, Washington, D.C., April.

Eberspächer, J., 1990, 1865-1990: 125 Years, J. Eberspächer Co., Esslingen, Germany, March. 


\section{EEI: Edison Electric Institute}

EEI, 1996, A Status Report on Climate Challenge Program's Voluntary Initiatives to Manage U.S. Electric Utility Greenhouse Gases, J.D. Kinsman, M. McGrath, R. McMahon, M. Rucker, R. Shiflett, and R. Tempchin, for presentation at $89^{\text {th }}$ Annual Meeting \& Exhibition, Air \& Waste Management Association, Nashville, Tenn., June.

EPA: U.S. Environmental Protection Agency

EPA, 1997, Emission Standards Reference Guide for Heavy-Duty and Nonroad Engines, U.S. Environmental Protection Agency, Air and Radiation, EPA420-F-97-014, http://www.epa.gov/otaq/cert/hd-cert/stds-eng.pdf, Sept.

EPA, 1998, Update of Heavy-Duty Engine Emission Conversion Factors for MOBILE6: Analysis of BSFCs and Calculation of Heavy-Duty Engine Emission Conversion Factors, U.S. Environmental Protection Agency, Air and Radiation, EPA420-P-98-015, http://www.epa.gov/orcdizux/ models/mobile6/m6hde004.pdf, May.

Espar, undated, The Comfort Company, brochure prepared by Espar Products, Inc., Mississauga, Ontario, Canada.

Espar, 1993, data sheet, Espar heater emissions, provided by Eric J. Jessiman, General Sales Manager, Espar Heater Systems, Mississauga, Ontario, Canada.

Greer, J.R., 1999, personal communication with J. Rex Greer (Pony Pack, Inc., Albuquerque, N.M.), Sept.

Hi-Z, 1996, Self-Powered Vehicle Engine Heater, preproposal submitted to California Air Resources Board, Sacramento, Calif., by Hi-Z Technology, Inc., San Diego, Calif., Aug.

IPS: International Power Sources

IPS, undated, literature sheet from International Power Sources, LLC, Burnsville, Minn.

Jessiman, E.J., 1996, personal communication with Eric J. Jessiman (General Sales Manager, Espar Heater Systems, Mississauga, Ontario, Canada), July.

Koziel, G., 1999, personal communication with Greg Koziel (Webasto Thermosystems, Lapeer, Mich.), July 26.

LaBelle, S.J., 1986, Don't Idle Your Profits Away!, Argonne National Laboratory white paper, Oct.

MSR: Mobile Source Report 
MSR, 1999, Texas Clean Cities Coalition to Test Truck Anti-Idling Devices, Mobile Source Report, p. 13, July 15.

Neff, N., 1999, BMW, Delphi Partner on Fuel Cells, Ward's Auto World, June.

Pannell, B., 1999, personal communication with Bobby Pannell (Vice President of Operations, Specific Climate Systems, Inc., Fort Worth, Texas), Dec.

PCG: Potomac Communication Group

PCG, 1995, Truck Cab Energy Storage Technology, memo and information on Shape Energy Resources Class 8 Truck Cab Environmental Control System provided to John Fairbanks (U.S. Department of Energy, Washington, D.C.) from Jim Pierobon (Potomac Communications Group, Washington, D.C.), April 10.

Pony Pack, Inc., undated, comparative emissions data, Pony Pack, Inc., Albuquerque, N.M.

Riemer, C., 1999, personal communication with Curt Riemer (R-Tex Trucking, Sioux City, Iowa), July 8.

SHAPE, 1997, DOE CabinAir ${ }^{T M}$ Introduction, presentation by Shape Energy Resources to U.S. Department of Energy, Washington, D.C., Oct. 21.

SCAQMD: South Coast Air Quality Management District

SCAQMD, 1997, Rule 163 Credits for Truck Stop Electrification, South Coast Air Quality Management District, http://www.arb.ca.gov/drdb/sc/curhtml/r1613.htm, adopted Nov. 14.

Tempchin, R., 1999, personal communication with Rick Tempchin (Edison Electric Institute, Washington, D.C.), July 19.

T-SEA, 1998, Truck-Stop Electrification May Eliminate Idling for Long-haul Trucks, press release by G. Baron, Executive Director, Truck Stop Electrification Alliance, published at http://www.truckinverter.com/readingroom/press/090198.html, Sept.

TMC: Truck Maintenance Council

TMC, 1995, Analysis of Costs from Idling and Parasitic Devices for Heavy Duty Trucks, Truck Maintenance Council Recommended Procedure 1108, American Trucking Association, Alexandria, Va., March.

TRI: Truck Research Institute

TRI, 1996, Commercial Driver Rest Area Requirements: No Room at the Inn, Truck Research Institute, Alexandria, Va. 
VIUS: Vehicle Inventory and Use Survey

VIUS 2000, U.S. Census Bureau, U.S. Department of Commerce, Washington, D.C., March.

Wang, M.Q., 1996, GREET 1.0—Transportation Fuel Cycles Model: Methodology and Use, ANL/ESD-33, Argonne National Laboratory, Argonne, Ill., June.

Wang, M.Q., 1999, personal communication about GREET 1.4 with Michael Wang (Argonne National Laboratory), also available on Worldwide Web (http://www.transportation.anl.gov/ ttrdc/greet/), July.

Webasto, 1999, personal communication with Megan Rowden (Webasto Thermosystems, Lapeer, Mich.), July.

Whiteside, D., 1996, personal communication with D. Whiteside (J.B. Hunt Trucking, Lowell, Ark.), Aug. 


\section{Appendix A Equipment and Emissions Data}

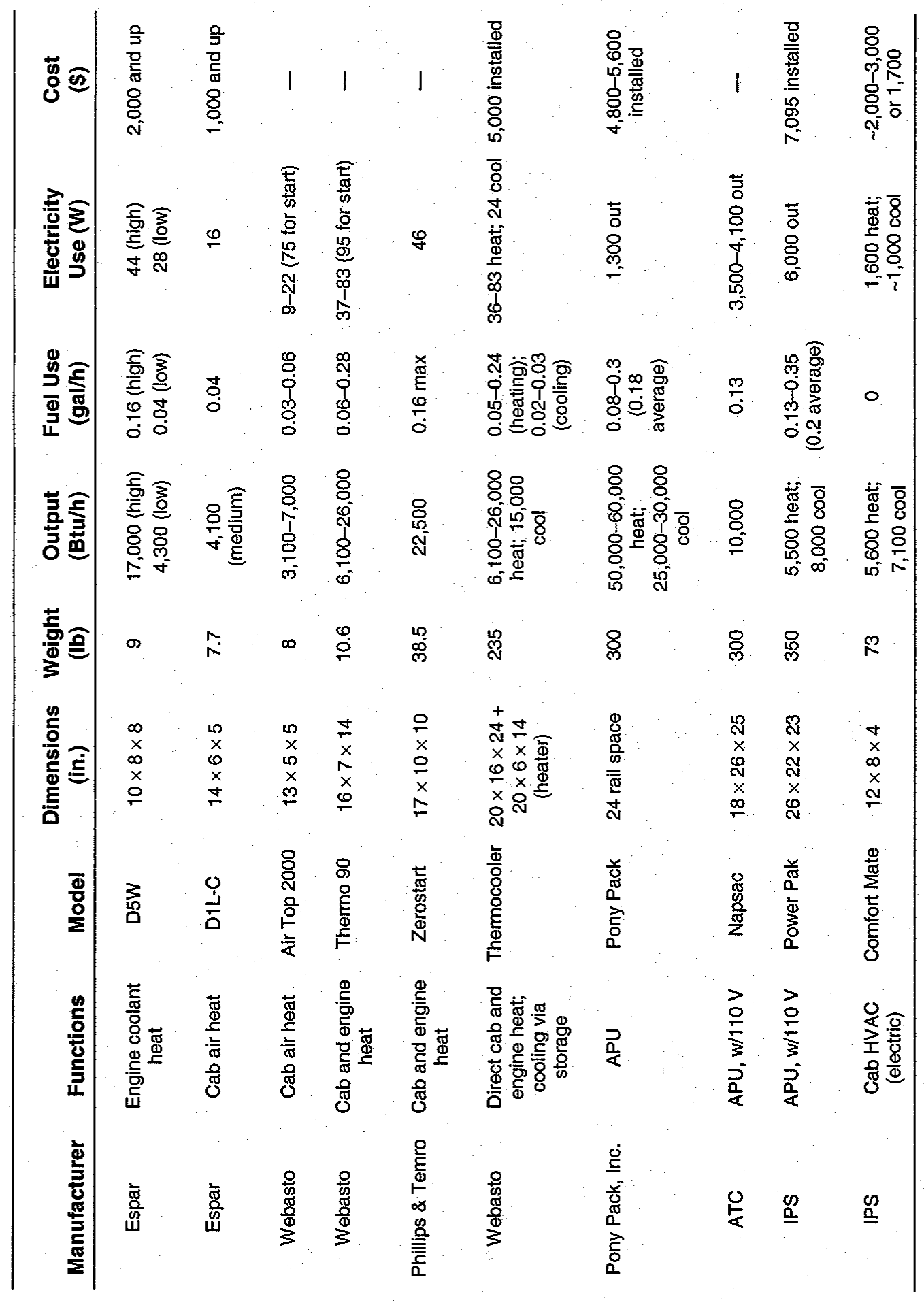


$\Delta$ 


\section{Appendix B Emissions Data}

Table B.1 Idling Emissions

\begin{tabular}{ccc|}
\hline & \multicolumn{2}{c|}{$\begin{array}{c}\text { Emissions }(\mathbf{g} / \mathbf{h}), \\
\text { by Season }\end{array}$} \\
\cline { 2 - 3 } Pollutant & Winter & Summer \\
\hline $\mathrm{VOC}$ & 12.6 & 12.5 \\
$\mathrm{CO}$ & 94.6 & 94.0 \\
$\mathrm{NO}_{\times}$ & 56.7 & 55.0 \\
$\mathrm{PM}_{10}$ & 2.57 & 2.57 \\
$\mathrm{CO}_{2}$ & 10,397 & 10,397 \\
\hline
\end{tabular}

Source: American Trucking Association Green Truck website, http://www. truckline.com/air_emissions/1420. $\mathrm{html}$ (updated October 5, 1998).
Table B.2 Direct-Fired Heater Emissions $^{a}(\mathrm{~g} / \mathrm{h})$

\begin{tabular}{|c|c|c|c|}
\hline Pollutant & $\begin{array}{c}\text { D5W Engine } \\
\text { Heater }\end{array}$ & $\begin{array}{c}\text { D1L-C Cab } \\
\text { Heater }\end{array}$ & Total \\
\hline THC & 0.030 & 0.144 & 0.174 \\
\hline $\mathrm{CO}$ & 0.408 & 0.029 & 0.437 \\
\hline $\mathrm{NO}_{x}$ & 0.030 & 0.234 & 0.264 \\
\hline $\mathrm{PM}_{10}$ & $n / i^{b}$ & $n / i^{b}$ & $n / i^{b}$ \\
\hline $\mathrm{CO}_{2}$ & 774 & 300 & 1,074 \\
\hline
\end{tabular}

a Espar, personal communication, undated (excludes electricity generation emissions).

b $n / i=$ no information.

Table B.3 Power

Plant Emissions $^{a}$ ( $\mathrm{g} / \mathrm{kWh}$ at user)

\begin{tabular}{cc|}
\hline Pollutant & $\begin{array}{c}\text { Annual } \\
\text { Emissions }\end{array}$ \\
\hline VOC & 0.0126 \\
$\mathrm{CO}$ & 0.1119 \\
$\mathrm{NO}_{\mathrm{x}}$ & 1.4045 \\
$\mathrm{PM}_{10}$ & 0.00809 \\
$\mathrm{SO}_{\mathrm{x}}$ & 1.7543 \\
$\mathrm{CH}_{4}$ & 0.0103 \\
$\mathrm{~N}_{2} \mathrm{O}$ & 0.0054 \\
$\mathrm{CO}_{2}$ & 701 \\
\hline
\end{tabular}

a Based on current U.S. mix $(0.8 \%$ oil, $21.1 \%$ natural gas, $54 \%$ coal, $12 \%$ nuclear, $11.7 \%$ other). Source: M. Wang, GREET 1.4

Model (available on

Worldwide Web at

http://www.transportation.

anl.gov/ttrdc/greet). 
$\Delta$

Table B.4 Pony Pack Emissions ${ }^{a}$

\begin{tabular}{|c|c|c|c|c|c|c|c|c|}
\hline \multirow[b]{2}{*}{ Model } & \multirow{2}{*}{$\begin{array}{c}\text { Displacement } \\
\text { (in. }{ }^{3} \text { ) }\end{array}$} & \multirow[b]{2}{*}{ Horsepower } & \multirow[b]{2}{*}{ rpm } & \multicolumn{5}{|c|}{$\begin{array}{l}\text { Emissions }(\mathrm{g} / \mathrm{h}), \\
\text { Winter }(3 \mathrm{hp}) / \text { Summer }(6 \mathrm{hp})^{\mathrm{b}}\end{array}$} \\
\hline & & & & $\mathrm{HC}$ & $\mathrm{NO}_{\mathrm{x}}$ & $\mathrm{NO}_{\mathrm{x}}+\mathrm{THC}$ & $\mathrm{CO}$ & PM \\
\hline Pony Pack 104 & 29 & 10 & 3,000 & $0.45 / 0.9$ & $11.55 / 23.10$ & $12 / 24$ & $7.5 / 15$ & $0.69 / 1.38$ \\
\hline Pony Pack 102 & 24 & 8 & 3,000 & 9.7 & 41.5 & 51.2 & 35.9 & 3.1 \\
\hline
\end{tabular}

a Source: Pony Pack, Inc. (undated).

b Emissions data for Pony Pack 102 are year-round, not seasonal. 